Research Article / Araştırma Makalesi

\title{
DETERMINING CRITERIA WEIGHTS AT ONLINE SHOPPING WEBSITE SELECTION FROM THE PERSPECTIVE OF YOUNG PEOPLE
}

\author{
Asst. Prof. Zafer YILMAZ (D) \\ TED University, FEAS, Ankara, Turkey, (zafer.yilmaz@tedu.edu.tr)
}

\begin{abstract}
In this study, it is aimed to determine the criteria that affect the selection of online shopping websites and find the weights of those criteria in decision making. In the first step, the online shopping website selection criteria are determined by reviewing the literature and interviewing with young people. Seven main criteria and their 23 sub-criteria are defined in total. A questionnaire is applied to the university students in Ankara. AHP methodology is used to evaluate the questionnaire and find the weights of the main and sub-criteria. Seven main criteria and their importance weights are found as follows: Website Quality (5.47\%), Payment Methods (8.67\%) Product Variety (16.15\%), Delivery and guarantee (31.4\%), Family-Friend Effect (8.26\%), Past Experiences (26.56\%) and Advertisements (3.49\%). In this study, the criteria weights are analyzed and compared according to gender and income level of the students. Although most of the criteria are taken into consideration in the literature separately, our study is the first comprehensive research which focuses all of them together by also considering the young people's perspective.
\end{abstract}

Keywords: AHP, Criteria for Online Shopping, Selection of Online Shopping Website.

\section{GENÇ İNSANLARIN PERSPEKTIFINDEN ONLINE ALIŞVERIŞ SITELERI SEÇIMINDEKİ KRITER AĞIRLIKLARININ BELIRLENMESI}

\begin{abstract}
ÖZET
Bu çalışmada, online alışveriş sitelerinin seçiminde etkili olan kriterlerinin belirlenmesi ve bu kriterlerin karar vermedeki ă̆ırlıklarının bulunması amaçlanmıştır. İlk adımda, literatür taranarak ve genç insanlarla görüşmeler yapılarak online alışveriş sitesi seçim kriterleri tanımlanmıştır. Toplamda yedi ana ve 23 alt kriter belirlenmiştir. İkinci adımda, bir anket hazırlanarak Ankara'da bulunan öğrencilere uygulanmıştır. AHP metodu anketi değerlendirmek, ana ve alt kriter a ğırlıklarını bulmak için kullanılmıştır. Son olarak, yedi ana kriter ve bunları önem dereceleri şöyle bulunmuştur: Web sitesi kalitesi $(\% 5,47)$, Ödeme Yöntemleri (\%8,67), Ürün Çeşitliliği $(\% 16,15)$, Ürün Gönderimi ve Garanti $(\% 31,4)$, AileArkadaş Etkisi (\%8,26), Geçmiş Deneyim (\%26,56), ve Reklamlar (\%3,49). Çalışmada ana kriter ve alt kriter ağırlıkları öğrencilerin cinsiyet ve gelir seviyelerine göre analiz edilmiş ve karşılaştırılmıştır. Her ne kadar literatürde çoğu kriter ayrı ayrı ele alınmış olsa da bu çalısma bütün kriterleri genç insanların da perspektifini dikkate alarak beraber değerlendiren ilk geniş çaplı araştırmadır.
\end{abstract}

Anahtar Kelimeler: AHP, Alışveriş Kriterleri, Online Alışveriş Sitesi Seçimi. 


\section{Introduction}

The use of the internet and the opportunities it offers us has expanded with the development of technology in the last two decades. People can communicate, follow the news, study and shop online on the internet. The improved technology provides people a lot of convenience and prevents them from wasting time. Online shopping has been growing very rapidly due to the developments in the internet technology. Consumers have more tendency to shop online in the recent years which increase the revenues of shopping online companies. For example, Amazon which is one of the most popular online shopping website around the world makes its owner the wealthiest businessperson in the world. 1.8 billion people worldwide purchased goods online in 2018. In the same year, global e-retail sales amount was $\$ 2.8$ trillion. Projections show that global e-retail sales are going to grow up to $\$ 4.48$ trillion by 2021 (Chen et al, 2018). In general, the market rate of online shopping has increased at a significant rate in recent years. Rates of online shopping have increased regardless of gender difference.

Many people prefer online shopping especially for grocery and daily used products in order not to waste time by going to shopping malls. Preventing from the diseases also affected the increase of shopping online. Eventually, the online shopping market share in the economies of the countries has increased rapidly in the last two decades which make the online shopping market more competitive. Hence, the online shopping market owners should consider the preferences of the customers and their approach to online shopping tools. The criteria which play important role on the consumers' shopping online preferences should be examined in detail by the online shopping market players in order to attract more customers.

In this research, a detailed literature survey is prepared in order to determine the criteria for choosing online websites. Next, the weights of the criteria are determined using Analytic Hierarch Process (AHP) methodology. Since young people are more interested in online shopping, in this research, people who are between 18 to 24 years old are focused for both interviewing with them to determine the criteria for online shopping website selection and applying the questionnaire for AHP methodology. The university students from Ankara-Turkey are selected for the interviews. The university students from different faculties are selected for the interviews. The interviews are done in groups of 3-4 students and the criteria that affect their opinions while choosing the online shopping websites are noted. The common criteria that are noted in all interviews are selected while determining the online shopping website selection criteria. The questionnaire is applied between October 10 and November 15, 2019. The rest of this paper is organized as follows: The next section describes the key literature on which this paper has been developed and hierarchy of our study. AHP methodology is defined in the third section. Results and analysis are given in the fourth section. The last section provides conclusions and opportunities for future researches.

\section{Literature Review and Criteria Analysis}

Online shopping websites are very popular nowadays. People prefer to stay home and shop online rather than going to the shopping malls or supermarkets. The share of online website in the market has increased rapidly which make it more competitive for the online shopping websites. In order to satisfy the customer demands, online shopping website owners should consider the opinions of their customers about their shopping websites. Thus, they can improve 
their website quality and service which leads to an increase on the number of customers. Young people have the biggest share in online shopping market. Therefore, their opinions about the online shopping websites, the criteria and criteria weights which affect the young customers' decisions to select the online shopping websites to shop should be examined in detail to assist the online shopping website owners. We reviewed the literature and interviewed with university students simultaneously in order to define the online website selection criteria that affect the consumer's choice. After the interviews and literature survey, we determined seven main criteria and 23 sub criteria for those main criteria. Eventually, main criteria and sub criteria which are identified by this research is given in Table 1.

Table 1: Main and Sub Criteria Determined in the Research

\begin{tabular}{|c|c|c|c|}
\hline Purpose & Main Criteria & Sub-Criteria & References \\
\hline \multirow{23}{*}{ 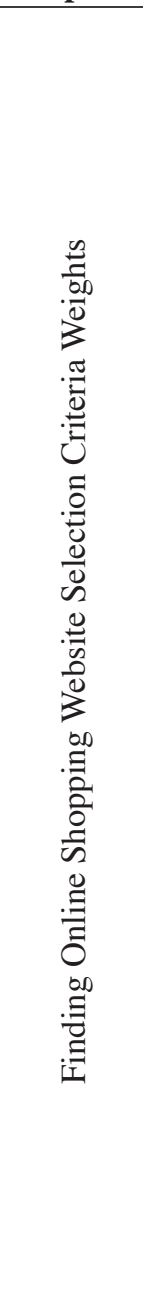 } & \multirow{4}{*}{$\begin{array}{l}\text { Website Quality } \\
\text { (WQ) }\end{array}$} & Design & \multirow{4}{*}{$\begin{array}{l}\text { Koufaris (2002), Wells } \\
\text { et al. (2011), Hyejeong } \\
\text { \& Linda (2009), Hsieh } \\
\& \text { Liao (2011), Sun \& } \\
\text { Lin (2009). }\end{array}$} \\
\hline & & Easy to Use, Access and Efficiency & \\
\hline & & Explanatory Information and Content & \\
\hline & & Special Treatments & \\
\hline & \multirow{3}{*}{$\begin{array}{l}\text { Payment } \\
\text { Methods (PM) }\end{array}$} & Payment Variety & \multirow{3}{*}{$\begin{array}{l}\text { Sun \& Lin (2009), Gao } \\
\text { (2005), Smith (2003), } \\
\text { Sheikh (2009), Sheikh } \\
\text { et al. (2015). }\end{array}$} \\
\hline & & Security and Security Policies & \\
\hline & & Privacy and Privacy Policies & \\
\hline & \multirow{4}{*}{$\begin{array}{l}\text { Product Variety } \\
(\mathrm{PV})\end{array}$} & Quality & \multirow{4}{*}{$\begin{array}{l}\text { Keeney (1999), Sun \& } \\
\text { Lin (2009), Sheikh et } \\
\text { al. (2015), }\end{array}$} \\
\hline & & Price Range & \\
\hline & & Different Sellers & \\
\hline & & Campaigns and Discounts & \\
\hline & \multirow{4}{*}{$\begin{array}{l}\text { Delivery and } \\
\text { Guarantee (DG) }\end{array}$} & Return Possibilities & \multirow{4}{*}{$\begin{array}{l}\text { Koyuncu (2004), Sun } \\
\& \text { Lin (2009), López et } \\
\text { al. (2005), }\end{array}$} \\
\hline & & Quality of Delivery & \\
\hline & & Fast Delivery Time & \\
\hline & & Guarantee Policies & \\
\hline & \multirow[b]{2}{*}{$\begin{array}{l}\text { Family Friend } \\
\text { Effect (FFE) }\end{array}$} & Family Recommendation & \multirow{2}{*}{$\begin{array}{l}\text { Whittler (2002), } \\
\text { Cheung \& Lee (2005), } \\
\text { Pires et al. (2004), } \\
\text { Lima et al. (2016). }\end{array}$} \\
\hline & & Friend Recommendation & \\
\hline & \multirow{3}{*}{$\begin{array}{l}\text { Past Experiences } \\
(\mathrm{PE})\end{array}$} & Bad Experiences & \multirow{3}{*}{$\begin{array}{l}\text { Wolfinbarger (2001), } \\
\text { - Zhou (2007), Sánchez- } \\
\text { García et al., (2012), } \\
\text { Tong (2010), Liu et al. } \\
\text { (2008). }\end{array}$} \\
\hline & & Good Experiences & \\
\hline & & Customer Support & \\
\hline & \multirow{3}{*}{$\begin{array}{l}\text { Advertisements } \\
\text { (A) }\end{array}$} & Social Media & \multirow{3}{*}{$\begin{array}{l}\text { Ducoffe (1996), Zhau } \\
\& \text { Bao (2002), Mislove, } \\
(2007) .\end{array}$} \\
\hline & & Other Advertisements Channels & \\
\hline & & Television, Radio and Newspaper & \\
\hline
\end{tabular}


Detailed information on how the main criteria and sub criteria are determined can be found in following subtitles.

\section{Website Quality}

Koufaris (2002) show that website quality is more effective when it is compared with the service quality and low prices of traditional shops. Moreover: fonts, visuals, shapes and layouts satisfy the consumer and spread positive impact on the websites (Wells et al, 2011). If websites offer specific information, people continue to shop from those websites (Hyejeong \& Linda, 2009). Consumers do not show tendency to shop outside of the websites they are accustomed to. So, the usefulness and quality of information will have positive effects on consumer attitudes to select online shopping websites (Hsieh \& Liao, 2011). On the other hand, when the websites offer special treatments, customers feel more e-satisfaction and loyalty to these online shopping websites (Sun \& Lin, 2009). According to Oliveira (2007), there is a significant bond association between website service quality and customer loyalty.

Our interviews show that students are also interested in the efficiency and accessibility of the online shopping websites. According to the interviews, the online shopping websites should direct people to the products they want. In addition, nobody wants to spend their time with complicated details. So, it is very important to arrange easy to use shopping websites. In this part of the study, four sub criteria for the main criteria website quality are defined based on the literature survey and interviews with students. Those sub criteria are: Design, easy to use (accessibility and efficiency), explanatory information (and content) and special treatments.

\section{Payment Methods}

The payment options offered by the online websites make the consumers' life easier. Shopping websites generally offer the following payment methods: credit card, debit card, virtual card, money order, intermediary payment institutions, and cash on delivery, payment by mobile phones and Electronic Funds Transfer. The variety of those payment options greatly affects people's choice to select the shopping website. On the other hand, the security and privacy are two important concerns of online shopping. For example, Sun and Lin's research shows that security and trust are the most important criteria for improving the competitive advantage of online shopping website (Sun \& Lin, 2009). It is quite important to avoid security concerns. If the online shopping websites take the related precautions, this will reassure the permanent consumers for the online shopping websites. For instance, online retailers need to share the formal privacy policies of their online security systems on their websites and implement superior encryption technology so that consumers can be easily informed about online retailers' security measures (Sun \& Lin, 2009). Gao (2005) shows that payment security is Pakistan's largest online shopping blockade. In this research, $52 \%$ of respondents classified payment protection as their main concern and $17 \%$ did not have a high level of confidence in online stores. Moreover, three other research results show that online shopping was affected by online payment and security purchasing decisions and convenience (Smith, 2003; Sheikh, 2009; Sheikh et al, 2015). In addition, in terms of privacy and security dangers, online retailers ought to post the formal security arrangements of their online security framework on their sites and receive predominant encryption innovation so that buyers can be effectively educated almost online retailers' security measures. For example, secure installment strategy ought to 
be given by B2C online retailers in arrange to ensure customers' protection and ensure their financial security (Liu, 2008).

In this part of the study, three sub criteria for the main criteria website quality are defined based on the literature survey and interviews with students. Those sub criteria are: Payment Variety, Security and Security Policies, Privacy and Privacy Policies.

\section{Product Variety}

Product variety factor has been among the criteria determined by past researches. The variety of products available on online websites allows a wide range of product quality and prices for the customers. Product variety and price ranges help people to decide what they want to buy from online shopping websites (Keeney, 1999). A past research shows that product's unit price has an impact on consumers to use the online shopping websites for both high and low involvement consumer (Sun \& Lin, 2009). So, there is a positive relation between product variety and online shopping website selection. It increases the motivation and convenience of consumers about the online shopping website. Some discount options or free items are offered by the online shopping website to attract the customers' attention when the customer adds a product to his/her shopping cart. On the other hand, the opportunity of buying from different sellers also affect consumers' shopping website selection since various marketers sell their products in different price ranges due to the competition between these sellers which really works for consumers who use online shopping. Otherwise sellers try to provide strong bond between their consumers (Sheikh et al, 2015). At the point when clients are happy with the items or administration they purchase, they will usually buy again from a similar provider.

The students who are interviewed point out that the quality of the product, campaigns and discounts have positive affect on their decision to select the online shopping website. They also agree that they search the online shopping websites for the campaigns and discounts after deciding to buy the related products. In this part of the study, four sub criteria for the main criteria product variety are defined based on the literature survey and interviews with students. Those sub criteria are: Quality, Price Range, Different Sellers, Campaigns and Discounts.

\section{Delivery and Guarantee}

Delivery and Guarantee are crucial factors for online shopping in order to have a sustainable business management. In this study, this criterion is determined by combining the information from the literature and comments that received from students. The online shopping organizations must guarantee the transportation of their products in a reasonable time period. Koyuncu (2004) shows that lack of information about guarantee is the dominant factor that influence the consumer's online shopping website selections. Sun \& Lin (2009) use fuzzy TOPSIS model which finds that trust is the most significant factor for competitive online websites. Consumers tend to choose those websites. If the firms publish their guarantee policies on their online websites, consumers will feel more comfortable to shop online at those websites. The efficiency of the online websites will be significantly reduced without the trust of guarantee. Trust helps to reduce the consumers' worries about the security and guarantee of the product and motivate them to use online shopping websites. López et al. (2005) discuss that website owners should create trust with products and implementation of guarantee to make difference between online shopping websites. Therefore, there is a positive relationship between product 
guarantee and usage of online shopping websites. On the other hand, delivery and packaging is another important factor. Recent surveys show that delivery time is a significant privilege over traditional markets. Consumer reviews obtained from the websites show that it is a great opportunity for the online shopping websites to increase their number of customers if they can provide fast and secure delivery without any broken parts.

In this part of the study, four sub criteria for the main criteria delivery and guarantee are defined based on the literature survey and interviews with students. Those sub criteria are: Return Possibilities, Quality of Delivery, Fast Delivery Time, and Guarantee Policies. We include the Return Possibilities among the sub-criteria of Delivery and Guarantee, since all the students interviewed point out that it is very important for them if the online shopping website gives the opportunity to the customers to return the products. This opportunity lets the students to feel more comfortable while buying the product.

\section{Family and Friend Effect}

Whittler (2002)'s research has demonstrated that companion gatherings can influence singular shopper choices, for instance, item assessment, buying plausibility and genuine buying. Other researches show that given the apparent hazard associated with web based shopping, they accepted that forthcoming on the web customers will solicit the assessment from their companions or online purchaser bunches before they settle on an online buy choice. While enlightening social impact could be certain (fruitful cases) or negative (awful experiences), they concentrated on positive instructive social impact in their investigation, since they were keen on encouraging web based shopping (Cheng \& Lee, 2005, Pires et al, 2004). Moreover, according to Lima et al. (2016), the customers will in general tune in to verbal suggestions from close families and family members, companions or even media before settling on a shopping choice. Lastly, Islam (2015) focus on different types of hypothesis for the factors affecting on online shopping behavior of consumers. The results show that family members, friends and peers' online experience and suggestions will positively influence online-buying behavior. In this part of the study, two sub criteria for the main criteria family and friend effect are defined based on the literature survey and interviews with students. Those sub criteria are: Family Recommendation and Friend Recommendation.

\section{Past Experience}

Wolfinbarger \& Gilly (2001) show that past experience is often an important factor for consumers. The impact is directed by purchasers' inspiration to shop on the web. Two past researches have demonstrated that experience affects emphatically goal to buy despite the fact that clients happy with past encounters may not generally come back to a similar supplier (Zhou, 2007, Sánchez-García et al., 2012). Liu et al. (2008) have recognized how critical the consumer loyalty is in web based shopping. Fruitful past buys and fulfillment that gets from them may build clients' exertion hope and execution anticipation. Correspondingly, Tong has led a cross-national investigation and inspected, among others, the immediate impacts of past web based shopping experience on apparent helpfulness and convenience (Tong, 2010). Last but not least, Ilias et al. (2014) showed that the normal execution of the web based shopping experience (execution anticipation) influences fulfillment just on high-experienced clients. Rather, the exertion expected to utilize internet shopping (exertion anticipation) and the client's faith in possess capacities to utilize web based shopping (self-viability) impact fulfillment just 
on low-experienced clients. Along these lines, fulfillment significantly affects aim to repurchase for the two sorts of clients, despite the fact that it is striking that the impact is littler for the high experienced gathering. In this part of the study, three sub criteria for the main criteria past experience are defined based on the literature survey and interviews with students. Those sub criteria are: Bad Experiences, Good Experiences, and Customer Support. The Customer Support criterion is especially included after the interviews since all the students interviewed complain about the customer support opportunities of the sellers. The students explain that they would feel more confident to know that there are customer support opportunities before they buy a product. Hence, they can easily contact with the customer support services in case they have problems with the products that they have bought.

\section{Advertisements and Social Media}

Most internet shopping destinations use web advertisement as one of the correspondence channels by which they can associate with online buyers for exchanges. Ducoffe (1996) and Zhau \& Bao (2002) explain that web ads may exploit addressable media innovation to choose fitting ads that are harmonious with shoppers' online practices, in this manner making the commercials progressively applicable to customers. At last, regardless of whether a sort of notice is adequate or not relies upon online purchasers' discernments with respect to whether the ads can satisfy their destinations. On the other hand, social media is a different factor that influences the consumers both positively and negatively. Social media has the biggest share both in daily life and business, and both producers and consumers have become more interested in these environments in their shopping processes. The fact that social media offers instant access to all users through mobile communication channels without the limit of time and space has brought social media to the forefront in marketing activities. Social media, where applications in the Web are used interactively, have become important for both personal and commercial communication (Mislove, 2007).

Naik \& Raman (2003) revealed that advertising strategies utilizing both TV and print media can affect positively a company's sales. Woo et al. (2015) study on media channels (i.e. TV, radio etc.) and consumer purchasing decisions and they find that media channels motivate the consumers to make purchases and those purchases vary depending on both sociodemographic variables and product categories. In this part of the study, three sub criteria for the main criteria advertisement and social media are defined based on the literature survey and interviews with students. Those sub criteria are: Social media, Television, Radio and Newspaper, Other Advertisements Channels.

Although most of the criteria are taken into consideration in above studies separately, our study is the first comprehensive research which focuses all of them together by also considering the results of interviews with university students. The determination of the main and sub-criteria in such a detailed way can be considered one of the main contribution of the study.

\section{Methodology}

AHP methodology is used in this study since the objective of the study is to find the weights of the defined criteria. The reason behind using AHP is that it is a very effective and widely used multi criteria decision making methodology especially if the researchers are 
defining the criteria weights and selecting or ranking the alternatives for a given objective like in our study. Myers and Alpert first introduced the AHP in 1968 and Saaty, developed it as a model, making it usable for solving decision-making problems in 1977 (Saaty, 1977). Three are many studies including many areas which use AHP to find solutions. For example, Çakır (2016) uses AHP in his study for the determination of 20 part time students who will be recruited in Adnan Menderes University. Eren \& Gür (2017) use AHP and TOPSIS methodologies to make selection for selection of third-party logistics (3PL) company in an online shopping site. Aydin et al. (2009) use AHP for optimal hospital location selection in Ankara.

AHP can be described as a decision making and estimation method used in case the decision hierarchy can be defined and it gives percentage distributions of decision points in terms of the factors affecting the decision. AHP is based on one-to-one comparisons on a decision hierarchy which uses a predefined comparison scale, both in terms of the factors affecting the decision and the significance of the decision points in terms of these factors. As a result, differences in importance turn into percentage distribution over decision points. The steps to be taken in order to solve a decision-making problem with AHP are described in the following paragraphs. At each step, explanations were made with the formulation. AHP has helped to find the determination of importance of factors affecting university students ' choice of online shopping website. A questionnaire which includes comparison tables for the main and sub-criteria is prepared and applied to 160 volunteer university students for this research. The AHP Hierarchy of the study is given in Figure 1. The main and sub criteria weights are obtained by using AHP method. The following paragraphs give a comprehensive explanation of AHP method.

\section{Figure 1: Sub Criteria Weights}

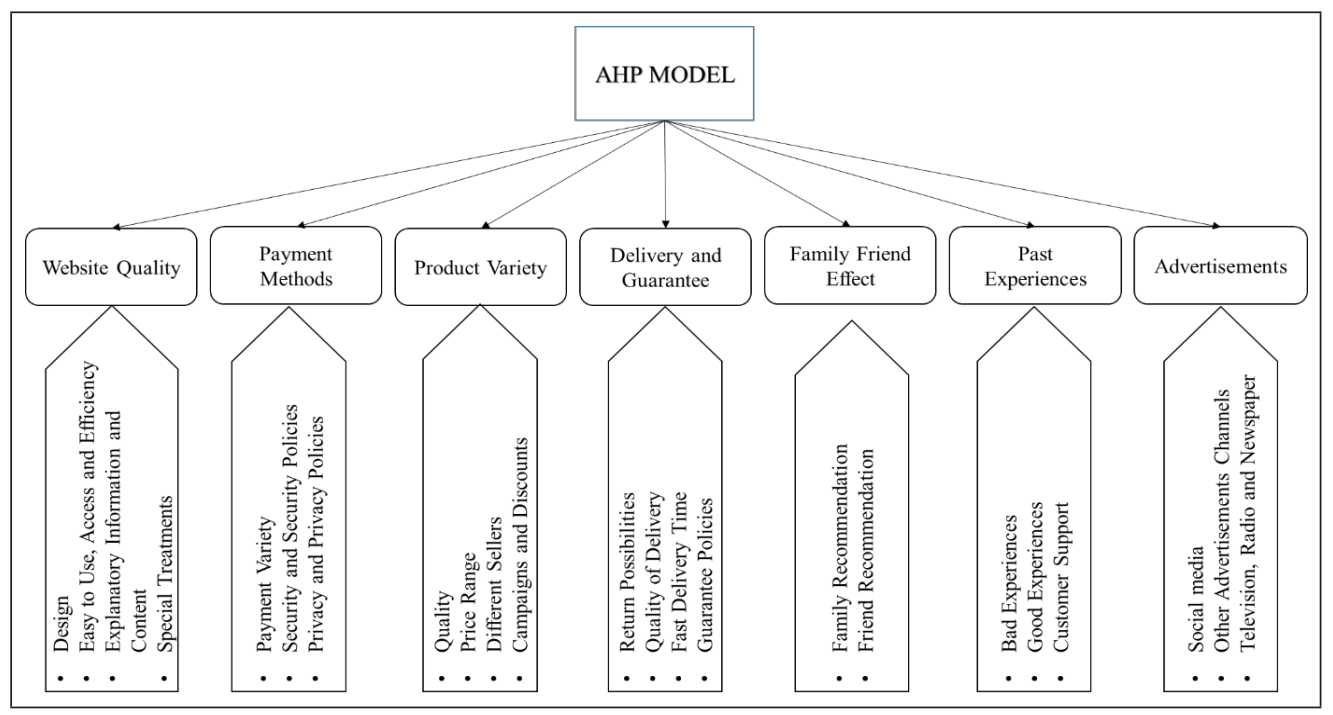




\section{Step 1. Decision Making Problem}

The definition of the decision-making problem consists of two stages. In the first stage, decision points are determined. In other words, the answer to the question of how many results will be evaluated is sought. In the second stage, the factors affecting the decision points are determined. In this study, the number of decision points is symbolized by $\mathrm{m}$ and the number of factors affecting decision points is symbolized by $\mathrm{n}$. It is important to make consistent and logical binary comparisons while specifying the number of factors that will affect the outcome in particular and making detailed descriptions of each factor.

Step 2. Creating a Cross-Factor Comparison Matrix

The inter-factor comparison matrix is a dimensional square matrix. The matrix components on the diagonal of this matrix is equal to one. The comparison matrix is shown below.

$$
A=\left[\begin{array}{cccc}
a_{11} & a_{12} & \cdots & a_{1 n} \\
a_{21} & a_{22} & \cdots & a_{2 n} \\
\vdots & \vdots & & \vdots \\
a_{n 1} & a_{n 2} & \cdots & a_{n n}
\end{array}\right]
$$

The components on the diagonal of the comparison matrix take the value one since the relevant factor is compared with itself. The comparison of the factors is made one to one and mutually according to their importance values. Factor scale in Table 2 is used for one-to-one comparison of factors.

\section{Table 2: Saaty's 1-9 Comparison Scale (Saaty, 1977)}

\begin{tabular}{cll}
\hline 1-9 comparison scale & \\
\hline 1 & Equal importance & Two activities contribute equally to the objective \\
\hline 3 & Moderate importance & $\begin{array}{l}\text { Experience and judgement slightly favor one activity over } \\
\text { another }\end{array}$ \\
\hline 5 & Strong importance & $\begin{array}{l}\text { Experience and judgement strongly favor one activity } \\
\text { over another }\end{array}$ \\
\hline 9 & Very strong importance & $\begin{array}{l}\text { An activity is favored very strongly over another; its } \\
\text { dominance demonstrated in practice }\end{array}$ \\
\hline $2,4,6,8$ & Extreme importance & $\begin{array}{l}\text { The evidence favoring one activity over another is of the } \\
\text { highest possible order of affirmation }\end{array}$ \\
\hline
\end{tabular}

If the first factor appears to be more important than the third factor, then the first row third column component $(i=1, j=3$ ) of the comparison matrix will take the value of three. Otherwise, if the more important preference is to be used in the comparison of the first factor with the third factor, then the first row of the comparison matrix will take the value of $1 / 3$ of the third column component. In the same comparison, if the factors are of equal importance 
in comparing the first factor and the third factor, then component one will be the value. Comparisons are made for values that lie above the diagonal of all values of the comparison matrix. For the components under the diagonal, it is natural to use the Equation 1.

$$
a_{j i}=\frac{1}{a_{i j}}
$$

Step 3. Determining Percentage Importance of Factors

The comparison matrix shows the importance levels of factors relative to each other in a particular logic. However, in order to determine the weights of these factors in the whole, in other words, percent significance distributions, column vectors forming the comparison matrix are used and column B with $\mathrm{n}$ and $\mathrm{n}$ components is formed. The calculation of column $\mathrm{B}$ vectors uses the Equation 2.

$$
b_{i j}=\frac{a_{i j}}{\sum_{i=1}^{n} a_{i j}}
$$

When the steps described above are repeated in other evaluation factors, the column number B will be the same as the number of factors. When B column vectors are combined in a matrix format, the $\mathrm{C}$ matrix shown below will be created.

$$
C=\left[\begin{array}{cccc}
c_{11} & c_{12} & \cdots & c_{1 n} \\
c_{21} & c_{22} & \cdots & c_{2 n} \\
\vdots & \vdots & & \vdots \\
c_{n 1} & c_{n 2} & \cdots & c_{n n}
\end{array}\right]
$$

By using the $\mathrm{C}$ matrix, the percent significance distributions showing the importance values of the factors relative to each other can be obtained. To do this, the arithmetic mean of the row components forming the matrix $\mathrm{C}$ as shown in Equation 3 is obtained and the column vector $\mathrm{W}$ (the Priority Vector) is obtained.

$$
W_{i}=\frac{\sum_{j=1}^{n} c_{i j}}{n}
$$

Step 4. Measuring Consistency in Factor Benchmarking

Although AHP has a consistent systematic in itself, the realism of the results depends on the consistency in one-to-one comparison between the decision-making factors. AHP proposes a process for measuring the consistency of these comparisons. The resulting Consistency Ratio (CR) and the priority vector provide the possibility to test the consistency of the comparisons. AHP is based on the essence of the CR calculation by comparing the number of factors with a coefficient $\lambda$ called the Basic Value. The vector D is obtained from the matrix product of the vector $\mathrm{W}$ by the comparison matrix $\mathrm{A}$ for the calculation of $\lambda$. 


$$
D=\left[\begin{array}{cccc}
a_{11} & a_{12} & \cdots & a_{1 n} \\
a_{21} & a_{22} & \cdots & a_{2 n} \\
\vdots & \vdots & & \vdots \\
a_{n 1} & a_{n 2} & \cdots & a_{n n}
\end{array}\right] x\left[\begin{array}{c}
w_{1} \\
w_{2} \\
\cdot \\
w_{n}
\end{array}\right]
$$

After calculating $\lambda$, the Consistency Index (CI) can be calculated using Equation 4 .

$$
C I=\frac{\lambda-n}{n-1}
$$

In the last step, CR is obtained (see Equation 5) by dividing the CI by standard correction value called Random Indicator (RI) which is shown in Table 3. The value corresponding to the number of factors is selected from Table 3.

Table 3: Random Consistency index

\begin{tabular}{cccccccccc}
\hline \multicolumn{10}{c}{ Random consistency index } \\
\hline $\mathrm{N}$ & $\mathrm{RI}$ & $\mathrm{N}$ & $\mathrm{RI}$ & $\mathrm{N}$ & $\mathrm{RI}$ & $\mathrm{N}$ & $\mathrm{RI}$ & $\mathrm{N}$ & $\mathrm{RI}$ \\
\hline 1 & 0 & 4 & 0.9 & 7 & 1.32 & 10 & 1.49 & 13 & 1.56 \\
\hline 2 & 0 & 5 & 1.12 & 8 & 1.41 & 11 & 1.51 & 14 & 1.57 \\
\hline 3 & 0.58 & 6 & 1.24 & 9 & 1.45 & 12 & 1.53 & 15 & 1.59 \\
\hline
\end{tabular}

In addition, a calculated $\mathrm{CR}$ value less than 0.10 indicates that the comparisons made by the decision maker are consistent. A CR value greater than 0.10 indicates either a calculation error in AHP or inconsistency in decision-making comparisons.

$$
C R=\frac{C I}{R I}
$$

Step 5. Finding Percentage Importance at each Decision Point for each Factor

One-to-one comparisons and matrix operations are repeated for the number of factors (n times). However, this time the size of the $\mathrm{G}$ comparison matrices to be used in the decision points for each factor will be $\mathrm{m} \times \mathrm{m}$. After each comparison, $\mathrm{S}$ column vectors are obtained which show $\mathrm{mx} 1$ size and percentage distributions of the factor evaluated according to the decision point.

Step 6. Finding Result Distribution at Decision Points

When the decision matrix $\mathrm{W}$ is multiplied with $\mathrm{S}$ vector, the column vector $\mathrm{L}$ with $\mathrm{m}$ elements is obtained. Column L gives the percentage distribution of decision points. In other words, the sum of the elements of the vector is one. This distribution also shows the order of importance of the decision points. 


$$
L=\left[\begin{array}{cccc}
s_{11} & s_{12} & \cdots & s_{1 n} \\
s_{21} & s_{22} & \cdots & s_{2 n} \\
\vdots & \vdots & & \vdots \\
s_{m 1} & s_{m 2} & \cdots & s_{m n}
\end{array}\right] x\left[\begin{array}{c}
w_{1} \\
w 2 \\
\cdot \\
w_{n}
\end{array}\right]=\left[\begin{array}{c}
l_{11} \\
l_{21} \\
\cdot \\
l_{m 1}
\end{array}\right]
$$

\section{Results and Analysis}

The questionnaire in this study is applied to 160 undergraduate university students. These students are from quite different age groups range from 18 to 25 . The numbers of female and male participants are 114 and 56 respectively. The focus group in this study is students in Ankara and those students are mostly funded by their families. Therefore, we have grouped the income levels into two parts which are $€$ 0-1000 and $€ 1001$ and above. The sample size of our study (160 participants) is quite in line with the literature. For example, in the study of Korkmaz et al. (2019), a questionnaire has been carried out for 86 personnel who work in a public institution. The sample size used in the study of Çakır (2016) is 50 students.

This study is based on a questionnaire which is applied to 160 students who are asked to fill out a comparison table according to their opinions. AHP methodology is used to find and analyze the criteria weights. For example, the students are asked to compare the main criteria website quality with other main criteria which are given in Table 4. Saaty's 1-9 scale is used by the students to compare the criteria. As an example, if a student thinks that website quality is more important than payment method she puts a cross sign on the "More Important" column at the left side of Table 4. The students first compared all main criteria with each other. The arithmetic means of the answers of 160 students are used in this step (pairwise comparison matrix) of AHP method.

\section{Table 4: Main Criteria Comparison Table}

\begin{tabular}{|c|c|c|c|c|c|c|c|c|c|}
\hline & 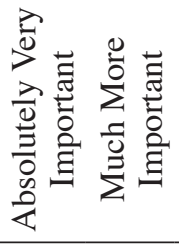 & 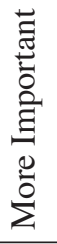 & 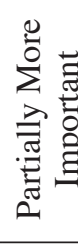 & 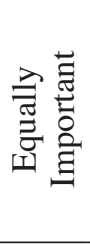 & 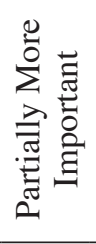 & 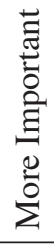 & 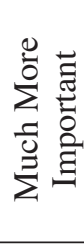 & 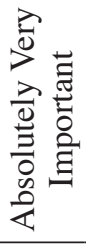 & \\
\hline & 9 & 5 & 3 & 1 & 3 & 5 & 7 & 9 & \\
\hline $\begin{array}{l}\text { Website } \\
\text { Quality }\end{array}$ & & & & & & & & & Payment Methods \\
\hline $\begin{array}{l}\text { Website } \\
\text { Quality }\end{array}$ & & & & & & & & & Product Variety \\
\hline $\begin{array}{l}\text { Website } \\
\text { Quality }\end{array}$ & & & & & & & & & $\begin{array}{l}\text { Delivery and } \\
\text { Guarantee }\end{array}$ \\
\hline $\begin{array}{l}\text { Website } \\
\text { Quality }\end{array}$ & & & & & & & & & Family Friend Affect \\
\hline $\begin{array}{l}\text { Website } \\
\text { Quality }\end{array}$ & & & & & & & & & Past Experiences \\
\hline
\end{tabular}




\section{Table 4 continued}

\begin{tabular}{|c|c|}
\hline $\begin{array}{l}\text { Website } \\
\text { Quality }\end{array}$ & Advertisements \\
\hline $\begin{array}{l}\text { Payment } \\
\text { Methods }\end{array}$ & Product Variety \\
\hline $\begin{array}{l}\text { Payment } \\
\text { Methods }\end{array}$ & $\begin{array}{l}\text { Delivery and } \\
\text { Guarantee }\end{array}$ \\
\hline $\begin{array}{l}\text { Payment } \\
\text { Methods }\end{array}$ & Family Friend Affect \\
\hline $\begin{array}{l}\text { Payment } \\
\text { Methods }\end{array}$ & Past Experiences \\
\hline $\begin{array}{l}\text { Payment } \\
\text { Methods }\end{array}$ & Advertisements \\
\hline $\begin{array}{l}\text { Product } \\
\text { Variety }\end{array}$ & $\begin{array}{l}\text { Delivery and } \\
\text { Guarantee }\end{array}$ \\
\hline $\begin{array}{l}\text { Product } \\
\text { Variety }\end{array}$ & Family Friend Affect \\
\hline $\begin{array}{l}\text { Product } \\
\text { Variety }\end{array}$ & Past Experiences \\
\hline $\begin{array}{l}\text { Product } \\
\text { Variety }\end{array}$ & Advertisements \\
\hline $\begin{array}{l}\text { Delivery } \\
\text { and } \\
\text { Guarantee }\end{array}$ & Family Friend Affect \\
\hline $\begin{array}{l}\text { Delivery } \\
\text { and } \\
\text { Guarantee }\end{array}$ & Past Experiences \\
\hline $\begin{array}{l}\text { Delivery } \\
\text { and } \\
\text { Guarantee }\end{array}$ & Advertisements \\
\hline $\begin{array}{l}\text { Family } \\
\text { Friend } \\
\text { Affect }\end{array}$ & Past Experiences \\
\hline $\begin{array}{l}\text { Family } \\
\text { Friend } \\
\text { Affect }\end{array}$ & Advertisements \\
\hline $\begin{array}{l}\text { Past } \\
\text { Experiences }\end{array}$ & Advertisements \\
\hline
\end{tabular}

Next the students are asked to compare the sub-criteria of each main criterion. For example, they are asked to compare the sub criteria for payment methods. If a student thinks that the sub-criteria payment variety is much more important than the sub-criteria security and security policies, she puts a cross sign on the "Much More Important" column at the left side of Table 5. The students are asked to compare all sub-criteria with each other for each main criterion. 
Table 5: Sub Criteria Comparison Table

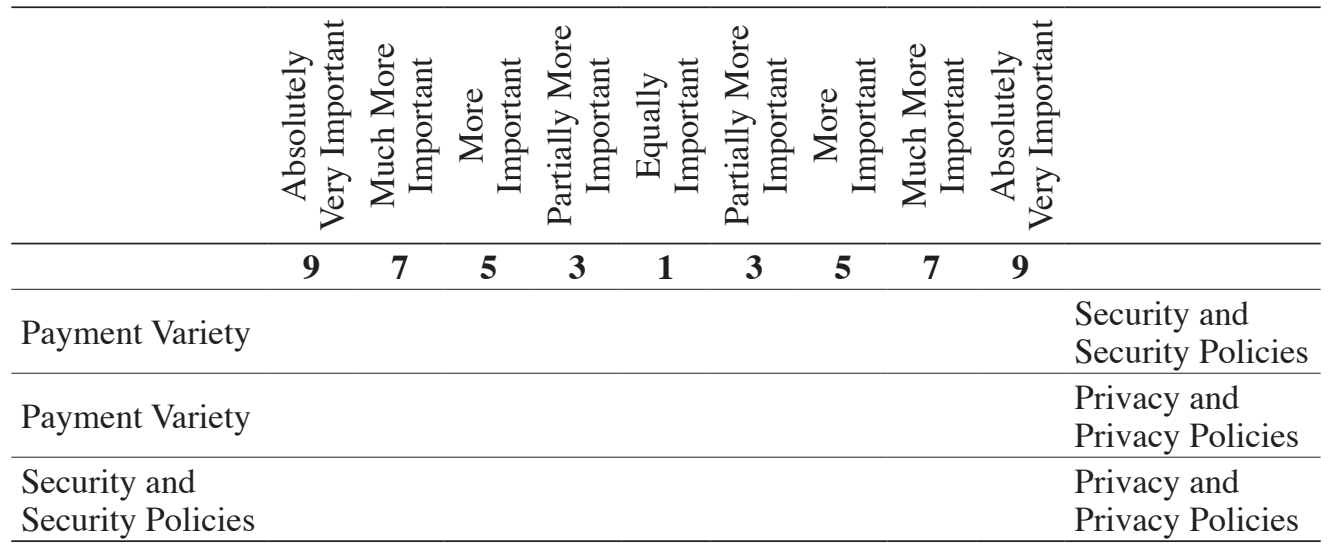

After the questionnaire is applied, aforementioned AHP methodology steps are applied to find the results. Table 6 is gives the results obtained from the last step of the AHP Methodology. Last column of Table 6 shows the weights of each main criterion in percentages. Names of main criteria are available with their abbreviations. Raw total column shows the accumulation of their number. The top three criteria with the highest percentage are found as Delivery and Guarantee (31.40\%), Past Experience (26.56\%) and Product Variety (16.15\%) respectively.

Table 6: Results of Overall Statistics

\begin{tabular}{lccc}
\hline Main Criteria & Row Total & Proportion & Percentage \\
\hline WQ & 0.38 & 0.05 & $5.47 \%$ \\
\hline PM & 0.61 & 0.09 & $8.67 \%$ \\
\hline PV & 1.13 & 0.16 & $16.15 \%$ \\
\hline DG & 2.20 & 0.31 & $31.40 \%$ \\
\hline FFE & 0.58 & 0.08 & $8.26 \%$ \\
\hline PE & 1.86 & 0.27 & $26.56 \%$ \\
\hline TOTAL & 0.24 & 0.03 & $3.49 \%$ \\
\hline
\end{tabular}

It is realized from the results that young people living in Ankara especially cares for delivery and guarantee conditions this is why they do not want to waste their money. Of course, their past experience about the online shopping websites will affect their decision for the next purchase. They think that product variety comes third which affect their decision to choose which online shopping website to shop. The other four criteria have weights below $10 \%$. Although the shopping websites spend considerable amount of money for the advertisements, surprisingly, we see that Advertisement criteria has the least weight (3.49\%).

After finding the weights of main criteria, we find the weights of sub-criteria for each main criterion by using the steps of AHP. Table 7 contains the results found for the sub-criteria weights for the main criterion website quality. Column A shows the weight of the main criterion website quality which is found before. Column B shows the weights of sub-criteria of website 
quality in terms of percentages. It is found that among four sub-criteria, "Easy to use, access and efficiency" has the highest weight (48.23\%). Young people think that, among sub-criteria of website quality, "explanatory information and content" of online shopping websites has the second highest weight (28.92\%) which affect their decision to shop.

Table 7: Weights of Sub-Criteria for Website Quality

\begin{tabular}{|c|c|c|c|c|}
\hline Main Criteria & $\mathbf{A}$ & Abbr. & Sub Criteria & B \\
\hline \multirow{4}{*}{$\begin{array}{l}\text { WQ } \\
\text { (Website Quality) }\end{array}$} & \multirow{4}{*}{$5.47 \%$} & $\mathrm{D}$ & Design & $7.60 \%$ \\
\hline & & EU & Easy to Use, Accessibility and Efficiency & $48.23 \%$ \\
\hline & & EIC & Explanatory Information and Content & $28.92 \%$ \\
\hline & & ST & Special Treatments & $15.25 \%$ \\
\hline
\end{tabular}

All sub-criteria weights are found for the corresponding main criteria which are given in Table 8. The weights of main criteria which are found before are given in Column A. Column B shows the weights of sub-criteria of all main criteria in terms of percentages. It is found that the consistency ratios are less than 0.1 (see CR Column of Table 8) which proves that the judgements for the questionnaire are consistent. CR value for the main criteria is found as 0.0298 .

Table 8: Weights of Sub-Criteria for Website Quality

\begin{tabular}{|c|c|c|c|c|c|}
\hline Main Criteria & A & $\begin{array}{c}\text { CR } \\
\text { Value }\end{array}$ & Abbr. & Sub Criteria & B \\
\hline \multirow{4}{*}{$\begin{array}{l}\text { WQ } \\
\text { (Website } \\
\text { Quality) }\end{array}$} & \multirow{4}{*}{$5.47 \%$} & \multirow{4}{*}{0.0857} & $\mathrm{D}$ & Design & $7.60 \%$ \\
\hline & & & EU & Easy to Use, Access and Efficiency & $48.23 \%$ \\
\hline & & & EIC & Explanatory Information and Content & $28.92 \%$ \\
\hline & & & ST & Special Treatments & $15.25 \%$ \\
\hline \multirow{3}{*}{$\begin{array}{l}\text { PM } \\
\text { (Payment } \\
\text { Method) }\end{array}$} & \multirow{3}{*}{$8.67 \%$} & \multirow{3}{*}{0.0366} & PV & Payment Variety & $9.37 \%$ \\
\hline & & & SSP & Security and Security Policies & $56.61 \%$ \\
\hline & & & PPP & Privacy and Privacy Policies & $34.01 \%$ \\
\hline \multirow{4}{*}{$\begin{array}{l}\text { PV } \\
\text { (Product } \\
\text { Variety) }\end{array}$} & \multirow{4}{*}{$16.15 \%$} & \multirow{4}{*}{0.0107} & $\mathrm{Q}$ & Quality & $39.79 \%$ \\
\hline & & & PR & Price Range & $23.20 \%$ \\
\hline & & & DS & Different Sellers & $7.96 \%$ \\
\hline & & & $\mathrm{CD}$ & Campaigns and Discoun & $29.04 \%$ \\
\hline \multirow{4}{*}{$\begin{array}{l}\text { DG } \\
\text { (Delivery and } \\
\text { Guarantee) }\end{array}$} & \multirow{4}{*}{$31.40 \%$} & \multirow{4}{*}{0.0398} & $\mathrm{RP}$ & Return Possib & $13.25 \%$ \\
\hline & & & QD & Quality of Deli & $25.75 \%$ \\
\hline & & & FDT & Fast Delivery Time & $22.63 \%$ \\
\hline & & & GP & Guarantee Policies & $38.36 \%$ \\
\hline \multirow{2}{*}{$\begin{array}{l}\text { FFE (Family } \\
\text { Friend Effect) }\end{array}$} & \multirow{2}{*}{$8.26 \%$} & & FR1 & Family Recommendation & $33.76 \%$ \\
\hline & & & FR2 & Friend Recommendation & $66.24 \%$ \\
\hline \multirow{3}{*}{$\begin{array}{l}\text { PE } \\
\text { (Past } \\
\text { Experience) }\end{array}$} & \multirow{3}{*}{$26.56 \%$} & \multirow{3}{*}{0.0386} & $\mathrm{BE}$ & Bad Experiences & $23.88 \%$ \\
\hline & & & GE & Good Experiences & $45.28 \%$ \\
\hline & & & CS & Customer Support & $30.84 \%$ \\
\hline \multirow{3}{*}{$\begin{array}{l}\text { A } \\
\text { (Advertisement) }\end{array}$} & \multirow{3}{*}{$3.49 \%$} & \multirow{3}{*}{0.0980} & SM & Social Media & $66.27 \%$ \\
\hline & & & $\mathrm{OA}$ & Other Advertisements Channels & $23.45 \%$ \\
\hline & & & TRN & Television, Radio and Newspaper & $10.28 \%$ \\
\hline
\end{tabular}


Table 8 shows the overall percentages of the main and sub-criteria found by using the survey results. There are seven main criteria and 23 different sub-criteria in total. The subcriteria which have the highest weights for each main criterion are given in gray shaded boxes in column B.

Among the Website Quality's sub-criteria, easy to use (Accessibility and Efficiency) has the highest percentage (48.23\%). The Payment Method's sub criteria are defined as Payment Variety, Security and Security Policies and Privacy and Privacy Policies. Among these sub criteria, Security and Security Policies has the highest percentage (56.61\%). Regarding the Product Variety's sub criteria, Quality has the highest percentage $(39.79 \%)$. The sub-criteria with the highest percentage is found as Guarantee Policies (38.36\%) for the main criterion Delivery and Guarantee. Considering the Family and Friend Effect's sub-criteria, Friend Recommendation has the highest percentage with big difference $(66.24 \%)$. This means that friend recommendation has a greater effect on young people's decisions rather than their families' effect. The sub-criteria with the highest percentage is found as Good Experience (45.28\%) for the main criterion Past Experience. So, if a customer has a good experience with an online shopping website she will for sure continue to shop again on this website. Last, the Advertisement's sub criteria are Social Media, Other Advertisements (Google, AdWords, YouTube), and Television, Radio and Newspaper. Among these sub criteria, Social Media has the highest percentage $(66.27 \%)$.

The online shopping websites should consider those weights found in order to improve their quality for their potential customers. If they do so, they will attract more attention and increase their number of customers.

Main criteria weights are multiplied with sub-criteria weights in order to sort 23 subcriteria. The percentages of all 23 sub-criteria according to their degree of importance are given in Figure 2. $\mathrm{X}$-axis of Figure 2 shows the names of sub-criteria (abbreviations are used) and $y$-axis gives the weights in percentages. Out of 23 sub-criteria Guarantee policies (12.04\%), Good Experience $(12.03 \%)$ and Customer Support $(8.19 \%)$ have the highest percentages respectively. We believe that our findings will give an idea for the online shopping website owners to focus on especially those sub-criteria with the highest importance degrees.

\section{Figure 2: Sub Criteria Weights}

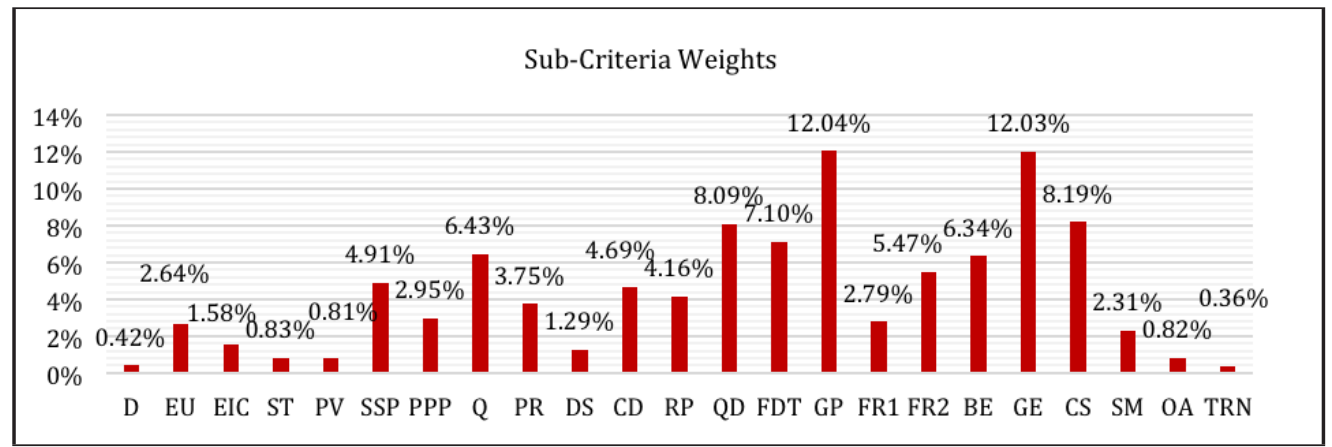

D: Design, EU: Easy to Use, EIC: Explanatory Information and Content, ST: Special Treatments, PV: Payment Variety, SSP: Security and Security Policies, PPP: Privacy and Privacy Policies, Q: Quality, PR: Price Range, DS: Different Sellers, CD: Campaigns and Discounts, RP: Return Possibilities, QD: Quality of Delivery, FDT: Fast Delivery Time, GP: Guarantee Policies, FR1: Family Recommendation, FR2: Friend Recommendation, BE: Bad Experiences, GE: Good Experiences, CS: Customer Support, SM: Social Media, OA: Other Advertisements Channels, TRN: Television, Radio and Newspaper 
In the next step of our study, the results are analyzed according to gender in order to see if the weights of main and sub-criteria change according to gender. Table 9 contains results for female and male participants. A1 and A2 columns give the weights of main criteria with respect to female and male participants respectively. B1 and B2 columns show the sub-criteria weights according to gender. For main criteria, it is found that the most important main criteria with the highest weight is Past Experience for females. However, it is Delivery and Guarantee for male participants. It is noticed that the weight of FFA is $10.31 \%$ for females while it is $6.02 \%$ for males. These significant differences are found since females are more emotional than males.

Table 9: Results According to Gender

\begin{tabular}{|c|c|c|c|c|c|c|}
\hline M.C. & $\begin{array}{c}\text { A1 } \\
\text { (Female) }\end{array}$ & $\begin{array}{c}\text { A2 } \\
\text { (Male) }\end{array}$ & Abr. & Sub-Criteria & $\begin{array}{c}\text { B1 } \\
\text { (Female) }\end{array}$ & $\begin{array}{c}\text { B2 } \\
\text { (Male) }\end{array}$ \\
\hline \multirow{4}{*}{ WQ } & \multirow{4}{*}{$4.78 \%$} & \multirow{4}{*}{$5.72 \%$} & $\mathrm{D}$ & Design & $7.64 \%$ & $6.84 \%$ \\
\hline & & & EU & Easy to Use, Access, Efficiency & $47.58 \%$ & $51.94 \%$ \\
\hline & & & EIC & Explanatory Info and Content & $29.17 \%$ & $26.29 \%$ \\
\hline & & & ST & Special Treatments & $15.60 \%$ & $14.92 \%$ \\
\hline \multirow{3}{*}{ PM } & \multirow{3}{*}{$8.61 \%$} & \multirow{3}{*}{$10.21 \%$} & PV & Payment Variety & $9.32 \%$ & $8.34 \%$ \\
\hline & & & $\mathrm{SSP}$ & Security and Security Policies & $61.28 \%$ & $34.68 \%$ \\
\hline & & & PPP & Privacy and Privacy Policies & $29.41 \%$ & $56.98 \%$ \\
\hline \multirow{4}{*}{ PV } & \multirow{4}{*}{$15.08 \%$} & \multirow{4}{*}{$14.63 \%$} & Q & Quality & $45.53 \%$ & $30.79 \%$ \\
\hline & & & PR & Price Range & $22.90 \%$ & $35.32 \%$ \\
\hline & & & DS & Different Sellers & $7.50 \%$ & $7.77 \%$ \\
\hline & & & $\mathrm{CD}$ & Campaigns and Discounts & $24.08 \%$ & $26.13 \%$ \\
\hline \multirow{4}{*}{ DG } & \multirow{4}{*}{$26.89 \%$} & \multirow{4}{*}{$34.94 \%$} & $\mathrm{RP}$ & Return Possibilities & $12.53 \%$ & $12.55 \%$ \\
\hline & & & QD & Quality of Delivery & $28.97 \%$ & $33.68 \%$ \\
\hline & & & FDT & Fast Delivery Time & $23.98 \%$ & $19.67 \%$ \\
\hline & & & GP & Guarantee Policies & $34.53 \%$ & $34.09 \%$ \\
\hline \multirow{2}{*}{ FFE } & \multirow{2}{*}{$10.31 \%$} & \multirow{2}{*}{$6.02 \%$} & FR1 & Family Recommendation & $36.43 \%$ & $29.67 \%$ \\
\hline & & & FR2 & Friend Recommendation & $63.57 \%$ & $70.33 \%$ \\
\hline \multirow{3}{*}{$\mathrm{PE}$} & \multirow{3}{*}{$30.83 \%$} & \multirow{3}{*}{$24.93 \%$} & $\mathrm{BE}$ & Bad Experiences & $31.77 \%$ & $17.89 \%$ \\
\hline & & & GE & Good Experiences & $41.05 \%$ & $41.00 \%$ \\
\hline & & & $\mathrm{CS}$ & Customer Support & $27.19 \%$ & $41.11 \%$ \\
\hline \multirow{3}{*}{ A } & \multirow{3}{*}{$3.51 \%$} & \multirow{3}{*}{$3.55 \%$} & SM & Social media & $66.46 \%$ & $69.35 \%$ \\
\hline & & & $\mathrm{OA}$ & Other Ad. Channels & $23.87 \%$ & $21.85 \%$ \\
\hline & & & TRN & TV, Radio and Newspaper & $9.67 \%$ & $8.80 \%$ \\
\hline
\end{tabular}

Column B1 shows the percentage distribution of the sub criteria for female participants. Regarding the Website Quality's sub criteria, Easy to use (Accessibility and Efficiency) has the highest percentage (47.58\%). Security and Security Policies has the highest percentage (61.28\%) among the Payment Method's sub criteria. Considering the Product Variety's sub criteria, Quality has the highest percentage (45.53\%). Among the Delivery and Guarantee's 
sub criteria, Guarantee Policies has the highest percentage (34.53\%). Considering the Family and Friend Effect's sub criteria, Friend Recommendation has the highest percentage with big difference (63.57\%). For the Past Experience' sub criteria, Good Experience has the highest percentage (41.05\%). Lastly, for the Advertisement's sub criteria, Social Media has the highest percentage $(66.46 \%)$.

Column B2 shows the percentage distribution of the sub criteria for male participants. Regarding the Website Quality's sub criteria, Easy to use (Accessibility and Efficiency) has the highest percentage (51.94\%). Privacy and Privacy Policies has the highest percentage (56.98\%) among the Payment Method's sub criteria. Considering the Product Variety's sub criteria, Price range has the highest percentage (35.32\%). Among the Delivery and Guarantee's sub criteria, Guarantee Policies have the highest percentage (34.09\%). Regarding the Family and Friend Effect's sub criteria, Friend Recommendation has the highest percentage with big difference (70.33\%). For the Past Experience' sub criteria, Customer Support has the highest percentage (41.11\%). Finally, for the Advertisement's sub criteria, Social Media has the highest percentage $(69.35 \%)$.

It is found that among payment methods' sub-criteria, Security and Security Policies is the most important one for females while it is Privacy and Privacy Policies for males. We also realize that among product variety sub-criteria, Quality is the most important one for females while it is Price Range for males.

Main criteria weights are multiplied with sub-criteria weights in order to sort the 23 sub-criteria with respect to gender. The percentages of all 23 sub-criteria according to their degree of importance are given in Figure 3. X-axis of Figure 3 shows the names of sub-criteria (abbreviations are used) and y-axis gives the weights in percentages (pink color for females and blue color for males).

\section{Figure 3: Sub Criteria Weights with Respect to Gender}

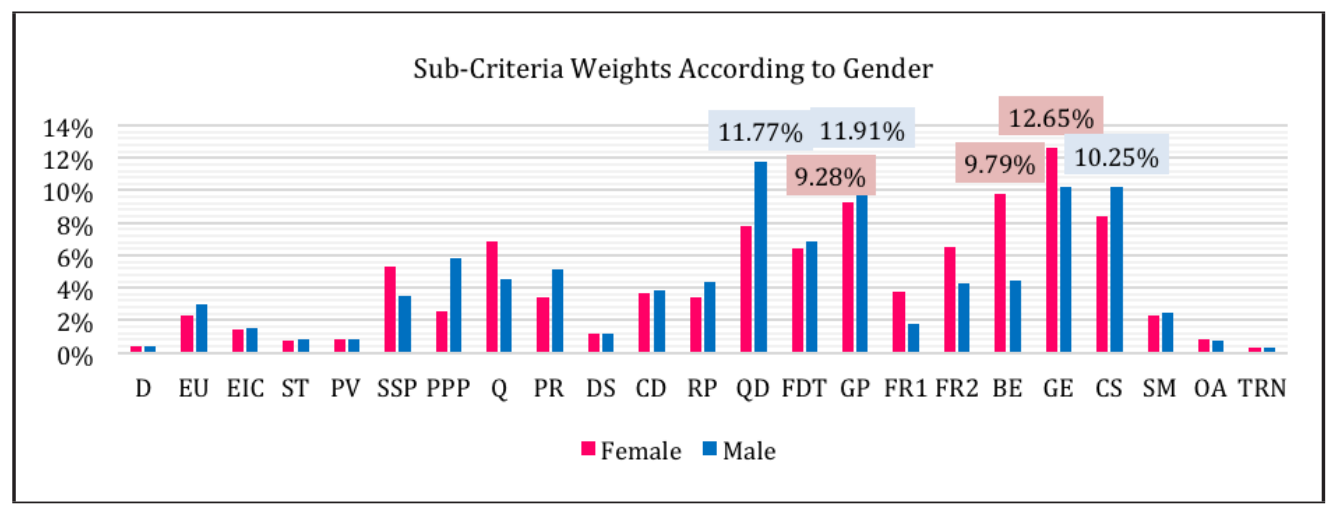

D: Design, EU: Easy to Use, EIC: Explanatory Information and Content, ST: Special Treatments, PV: Payment Variety, SSP: Security and Security Policies, PPP: Privacy and Privacy Policies, Q: Quality, PR: Price Range, DS: Different Sellers, CD: Campaigns and Discounts, RP: Return Possibilities, QD: Quality of Delivery, FDT: Fast Delivery Time, GP: Guarantee Policies, FR1: Family Recommendation, FR2: Friend Recommendation, BE: Bad Experiences, GE: Good Experiences, CS: Customer Support, SM: Social Media, OA: Other Advertisements Channels, TRN: Television, Radio and Newspaper 
Out of 23 sub-criteria Good Experiences, Bad Experiences and Guarantee Policies have the highest percentages respectively for female participants. Obviously, Good Experience has the highest percentage among these all criteria (12.65\%). Out of 23 sub-criteria, Guarantee Policies, Quality of Delivery and Customer Support have the highest percentages respectively for male participants. Undoubtedly, Guarantee Policies has the highest percentage among those all sub-criteria (11.91\%).

In the next step of our study, the results are analyzed according to income level in order to see if the weights of main and sub-criteria change according to incomes of participants. Table 10 contains results of participants who have income less than $€ 1000$ and above $€ 1001$. A1 and A2 columns give the weights of main criteria with respect to income level of the participants respectively. B1 and B2 columns show the sub-criteria weights according to income levels. For main criteria, we find that the most important main criteria with the highest weight is Delivery and Guarantee for both types of participants. We realize that the sort of first three highest important sub-criteria is same for both type of participants. The only difference is that the fourth most important sub-criteria is Payment Method for participants with an income level less than $€_{1000}$ per month while the fourth most important sub-criteria is Family and Friendship Effect for the participants with an income level above $€ 1001$ per month. We believe that this is because, the participants with low income level care about payment methods in order not to lose their money. In general, we can explain that income level has not a great effect on the decisions of participants with respect to main criteria.

Table 10: Results According to Income Level

\begin{tabular}{|c|c|c|c|c|c|c|}
\hline M.C. & $\begin{array}{c}\mathrm{A} 1 \\
(も 0-1000)\end{array}$ & $\begin{array}{c}\mathrm{A} 2 \\
\text { (も1001 above) }\end{array}$ & Abrv. & SUB-CRITERIA & $\begin{array}{c}\text { B1 } \\
(\text { 毛-1000) }\end{array}$ & $\begin{array}{c}\text { B2 } \\
(\text { (1001 above) }\end{array}$ \\
\hline \multirow{4}{*}{ WQ } & \multirow{4}{*}{$5.53 \%$} & \multirow{4}{*}{$5.21 \%$} & $\mathrm{D}$ & Design & $7.40 \%$ & $7.91 \%$ \\
\hline & & & EU & $\begin{array}{c}\text { Easy to Use, Access } \\
\text { and Efficient }\end{array}$ & $43.70 \%$ & $52.18 \%$ \\
\hline & & & EIC & $\begin{array}{c}\text { Explanatory } \\
\text { Information Content }\end{array}$ & $31.76 \%$ & $26.42 \%$ \\
\hline & & & ST & Special Treatments & $17.14 \%$ & $13.49 \%$ \\
\hline \multirow{3}{*}{ PM } & \multirow{3}{*}{$10.31 \%$} & \multirow{3}{*}{$7.62 \%$} & PV & Payment Variety & $9.92 \%$ & $8.93 \%$ \\
\hline & & & SSP & $\begin{array}{c}\text { Security and } \\
\text { Security Policies }\end{array}$ & $53.88 \%$ & $54.38 \%$ \\
\hline & & & PPP & $\begin{array}{c}\text { Privacy and Privacy } \\
\text { Policies }\end{array}$ & $36.21 \%$ & $36.69 \%$ \\
\hline \multirow{4}{*}{ PV } & \multirow{4}{*}{$15.88 \%$} & \multirow{4}{*}{$16.49 \%$} & Q & Quality & $45.76 \%$ & $35.70 \%$ \\
\hline & & & PR & Price Range & $24.28 \%$ & $28.08 \%$ \\
\hline & & & DS & Different Sellers & $6.85 \%$ & $8.76 \%$ \\
\hline & & & $\mathrm{CD}$ & $\begin{array}{l}\text { Campaigns and } \\
\text { Discounts }\end{array}$ & $23.10 \%$ & $27.45 \%$ \\
\hline
\end{tabular}


Table 10 continued

\begin{tabular}{|c|c|c|c|c|c|c|}
\hline \multirow{4}{*}{ DG } & \multirow{4}{*}{$29.54 \%$} & \multirow{4}{*}{$30.03 \%$} & $\mathrm{RP}$ & Return Possibilities & $11.41 \%$ & $13.86 \%$ \\
\hline & & & QD & Quality of Delivery & $29.97 \%$ & $32.13 \%$ \\
\hline & & & FDT & Fast Delivery Time & $23.30 \%$ & $20.90 \%$ \\
\hline & & & GP & Guarantee Policies & $35.31 \%$ & $33.11 \%$ \\
\hline \multirow{2}{*}{ FFE } & \multirow{2}{*}{$8.14 \%$} & \multirow{2}{*}{$8.82 \%$} & FR1 & $\begin{array}{c}\text { Family } \\
\text { Recommendation }\end{array}$ & $35.71 \%$ & $32.23 \%$ \\
\hline & & & FR2 & $\begin{array}{c}\text { Friend } \\
\text { Recommendation }\end{array}$ & $64.29 \%$ & $67.77 \%$ \\
\hline \multirow{3}{*}{$\mathrm{PE}$} & \multirow{3}{*}{$27.27 \%$} & \multirow{3}{*}{$28.25 \%$} & $\mathrm{BE}$ & Bad Experiences & $24.08 \%$ & $23.98 \%$ \\
\hline & & & GE & Good Experiences & $43.73 \%$ & $45.89 \%$ \\
\hline & & & $\mathrm{CS}$ & Customer Support & $32.19 \%$ & $30.13 \%$ \\
\hline \multirow{3}{*}{$\mathrm{A}$} & \multirow{3}{*}{$3.33 \%$} & \multirow{3}{*}{$3.59 \%$} & SM & Social media & $67.32 \%$ & $66.89 \%$ \\
\hline & & & $\mathrm{OA}$ & Other Ad. Channels & $24.32 \%$ & $21.69 \%$ \\
\hline & & & TRN & $\begin{array}{l}\text { TV, Radio and } \\
\text { Newspaper }\end{array}$ & $8.36 \%$ & $11.42 \%$ \\
\hline
\end{tabular}

Column B1 shows the percentage distribution of the sub criteria for the students who has income between $€$ 0-1000 per month. Considering the Website Quality's sub criteria, Easy to use (Accessibility and Efficiency) has the highest percentage (43.70\%). Among the Payment Method's sub criteria, Security and Security Policies has the highest percentage (53.88\%). Regarding the Product Variety's sub criteria, Quality has the highest percentage (45.76\%). For the Delivery and Guarantee's sub criteria, Guarantee Policies have the highest percentage $(35.31 \%)$. For the Family and Friend Affect's sub criteria, Friend Recommendation has the highest percentage with big difference (64.29\%). Among the Past Experience' sub criteria, Good Experience has the highest percentage (43.73\%). Finally, for the Advertisement's sub criteria, Social Media has the highest percentage (67.32\%).

Column B2 shows the percentage distribution of the sub criteria for the students who has income between above $€ 1000$ per month. Regarding the Website Quality's sub criteria, Easy to use (Accessibility and Efficiency) has the highest percentage (52.18\%). Among the Payment Method's sub criteria, Security and Security Policies has the highest percentage (54.38\%). Among the Product Variety's sub criteria, Quality has the highest percentage $(35.70 \%)$. For the Delivery and Guarantee's sub criteria, Guarantee Policies has the highest percentage (33.11\%). Considering the Family and Friend Affect's sub criteria, Friend Recommendation has the highest percentage with big difference (67.77\%). For the Past Experience' sub criteria, Good Experience has the highest percentage (45.89\%). Last of all, for the Advertisement's sub criteria, Social Media has the highest percentage (66.89\%).

In general, it is explained that income level has not a great effect on the decisions of participants with respect to sub-criteria. 
Main criteria weights are multiplied with the sub-criteria weights in order to sort 23 subcriteria with respect to income level. The percentages of all 23 sub-criteria according to their degree of importance are given in Figure 4 . X-axis of Figure 4 shows the names of sub-criteria (abbreviations are used) and $y$-axis gives the weights in percentages (red color for participants with an income level less than $€ 1000$ and blue color for participants with an income level greater than $€ 1001)$.

\section{Figure 4: Sub Criteria Weights with Respect to Income Level}

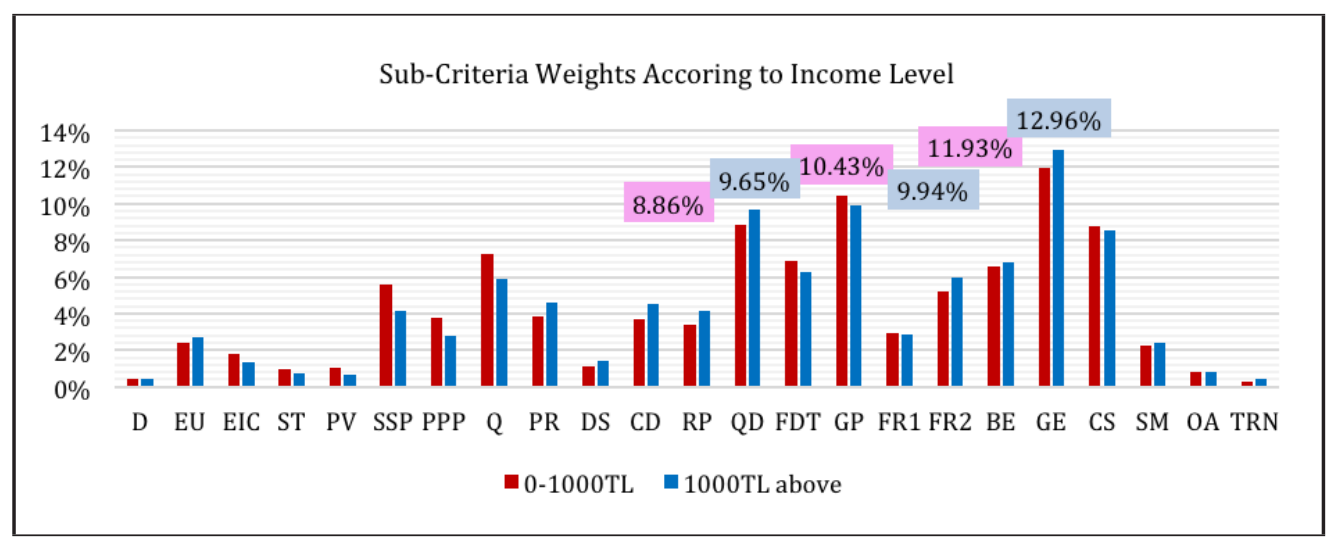

D: Design, EU: Easy to Use, EIC: Explanatory Information and Content, ST: Special Treatments, PV: Payment Variety, SSP: Security and Security Policies, PPP: Privacy and Privacy Policies, Q: Quality, PR: Price Range, DS: Different Sellers, CD: Campaigns and Discounts, RP: Return Possibilities, QD: Quality of Delivery, FDT: Fast Delivery Time, GP: Guarantee Policies, FR1: Family Recommendation, FR2: Friend Recommendation, BE: Bad Experiences, GE: Good Experiences, CS: Customer Support, SM: Social Media, OA: Other Advertisements Channels, TRN: Television, Radio and Newspaper

Out of 23 sub-criteria Good Experiences, Guarantee Policies and Quality of Delivery have the highest percentages respectively for both types of income levels. When the first and second highest sub criteria are compared it is found that there is no big gap between them. In general, we can explain that income levels cause differences on the weights of sub-criteria but those differences do not affect the place of the first four sub-criteria with highest weights. However, while the fifth most important sub-criteria for the students with an income level less than $€ 1000$ is Quality, it is Bad Experience for the students with an income level greater than $€ 1001$. So, it is concluded that the weights of average and less important sub-criteria change according to income levels.

Table 11 contains all results for the weights of main criteria with respect to all participants, female students, male students, the students with an income level less than 1000 and greater than $€ 1001$ options. 
Table 11: Main Criteria Weights for Different Focus Groups

\begin{tabular}{lccccc}
\hline Main Criteria & $\begin{array}{c}\text { All } \\
\text { Participants }\end{array}$ & Male & Female & $\begin{array}{c}\text { 1000 and } \\
\text { Below }\end{array}$ & $\begin{array}{c}\mathbf{1 0 0 1} \text { and } \\
\text { Above }\end{array}$ \\
\hline Website Quality & $5.46 \%$ & $5.72 \%$ & $4.78 \%$ & $5.53 \%$ & $5.21 \%$ \\
\hline Payment Methods & $8.66 \%$ & $10.21 \%$ & $8.61 \%$ & $10.31 \%$ & $7.62 \%$ \\
\hline Product Variety & $\mathbf{1 6 . 1 4 \%}$ & $\mathbf{1 4 . 6 3 \%}$ & $\mathbf{1 5 . 0 8 \%}$ & $\mathbf{1 5 . 8 8 \%}$ & $\mathbf{1 6 . 4 9 \%}$ \\
\hline Delivery and Guarantee & $\mathbf{3 1 . 3 8 \%}$ & $\mathbf{3 4 . 9 4 \%}$ & $\mathbf{2 6 . 8 9 \%}$ & $\mathbf{2 9 . 5 4 \%}$ & $\mathbf{3 0 . 0 3 \%}$ \\
\hline Family Friendship Effect & $8.35 \%$ & $6.02 \%$ & $10.31 \%$ & $8.14 \%$ & $8.82 \%$ \\
\hline Past Experiences & $\mathbf{2 6 . 5 5 \%}$ & $\mathbf{2 4 . 9 3 \%}$ & $\mathbf{3 0 . 8 3 \%}$ & $\mathbf{2 7 . 2 7 \%}$ & $\mathbf{2 8 . 2 5 \%}$ \\
\hline Advertisements & $3.46 \%$ & $3.55 \%$ & $3.51 \%$ & $3.33 \%$ & $3.59 \%$ \\
\hline
\end{tabular}

Highest three main criteria weights with respect to each focus group are shown in bold letters. The main criterion with highest weight percentage is Delivery and Guarantee for all students (All participants column in Table 11), males and both income levels, but it is Past Experiences for female students. Females and students with an income level greater than €1001 think that fourth most important criteria is Family Friendship Affect while it is Payment Methods for other focus groups. In addition, all the results show that, the weights of the Product Variety criteria remains almost same for all focus groups and it changes approximately from $14 \%$ to $16 \%$.

Table 12 contains results for the weights of all sub-criteria of main criteria with respect to all participants, female students, male students, the students with an income level less than $€_{1000}$ and greater than $€ 1001$ options.

Table 12: Sub-Criteria Weights for Different Focus Groups

\begin{tabular}{|c|c|c|c|c|c|c|}
\hline $\begin{array}{l}\text { Main } \\
\text { Criteria }\end{array}$ & Sub-Criteria & $\begin{array}{c}\text { B } \\
\text { (All } \\
\text { Participants) }\end{array}$ & $\begin{array}{c}\text { B1 } \\
\text { (Female) }\end{array}$ & $\begin{array}{c}\text { B2 } \\
\text { (Male) }\end{array}$ & $\begin{array}{c}\text { B3 } \\
(\text { 半 } 0-1000)\end{array}$ & $\begin{array}{c}\text { B4 } \\
\text { (も 1001 } \\
\text { Above) }\end{array}$ \\
\hline \multirow{4}{*}{ WQ } & Design & $7.60 \%$ & $7.64 \%$ & $6.84 \%$ & $7.40 \%$ & $7.91 \%$ \\
\hline & $\begin{array}{l}\text { Easy to Use Access, } \\
\text { Efficiency }\end{array}$ & $48.23 \%$ & $47.58 \%$ & $51.94 \%$ & $43.70 \%$ & $52.18 \%$ \\
\hline & $\begin{array}{l}\text { Explanatory Info and } \\
\text { Content }\end{array}$ & $28.92 \%$ & $29.17 \%$ & $26.29 \%$ & $31.76 \%$ & $26.42 \%$ \\
\hline & Special Treatments & $15.25 \%$ & $15.60 \%$ & $14.92 \%$ & $17.14 \%$ & $13.49 \%$ \\
\hline \multirow{3}{*}{ PM } & Payment Variety & $9.37 \%$ & $9.32 \%$ & $8.34 \%$ & $9.92 \%$ & $8.93 \%$ \\
\hline & $\begin{array}{l}\text { Security and Security } \\
\text { Policies }\end{array}$ & $56.61 \%$ & $61.28 \%$ & $34.68 \%$ & $53.88 \%$ & $54.38 \%$ \\
\hline & $\begin{array}{l}\text { Privacy and Privacy } \\
\text { Policies }\end{array}$ & $34.01 \%$ & $29.41 \%$ & $56.98 \%$ & $36.21 \%$ & $36.69 \%$ \\
\hline \multirow{4}{*}{ PV } & Quality & $39.79 \%$ & $\mathbf{4 5 . 5 3 \%}$ & $30.79 \%$ & $45.76 \%$ & $35.70 \%$ \\
\hline & Price Range & $23.20 \%$ & $22.90 \%$ & $35.32 \%$ & $24.28 \%$ & $28.08 \%$ \\
\hline & Different Sellers & $7.96 \%$ & $7.50 \%$ & $7.77 \%$ & $6.85 \%$ & $8.76 \%$ \\
\hline & $\begin{array}{l}\text { Campaigns and } \\
\text { Discounts }\end{array}$ & $29.04 \%$ & $24.08 \%$ & $26.13 \%$ & $23.10 \%$ & $27.45 \%$ \\
\hline
\end{tabular}


Table 12 continued

\begin{tabular}{lllllll}
\hline \multirow{2}{*}{ DG } & Return Possibilities & $13.25 \%$ & $12.53 \%$ & $12.55 \%$ & $11.41 \%$ & $13.86 \%$ \\
\cline { 2 - 6 } & Quality of Delivery & $25.75 \%$ & $28.97 \%$ & $33.68 \%$ & $29.97 \%$ & $32.13 \%$ \\
\cline { 2 - 7 } & Fast Delivery Time & $22.63 \%$ & $23.98 \%$ & $19.67 \%$ & $23.30 \%$ & $20.90 \%$ \\
\cline { 2 - 7 } & Guarantee Policies & $\mathbf{3 8 . 3 6 \%}$ & $\mathbf{3 4 . 5 3 \%}$ & $\mathbf{3 4 . 0 9 \%}$ & $\mathbf{3 5 . 3 1 \%}$ & $\mathbf{3 3 . 1 1 \%}$ \\
\hline \multirow{2}{*}{ FFE } & $\begin{array}{l}\text { Family } \\
\text { Recommendation }\end{array}$ & $33.76 \%$ & $36.43 \%$ & $29.67 \%$ & $35.71 \%$ & $32.23 \%$ \\
\cline { 2 - 7 } & $\begin{array}{l}\text { Friend } \\
\text { Recommendation }\end{array}$ & $\mathbf{6 6 . 2 4 \%}$ & $\mathbf{6 3 . 5 7 \%}$ & $\mathbf{7 0 . 3 3 \%}$ & $\mathbf{6 4 . 2 9 \%}$ & $\mathbf{6 7 . 7 7 \%}$ \\
\hline \multirow{2}{*}{ PE } & Bad Experiences & $23.88 \%$ & $31.77 \%$ & $17.89 \%$ & $24.08 \%$ & $23.98 \%$ \\
\hline & Good Experiences & $\mathbf{4 5 . 2 8 \%}$ & $\mathbf{4 1 . 0 5 \%}$ & $41.00 \%$ & $\mathbf{4 3 . 7 3 \%}$ & $\mathbf{4 5 . 8 9 \%}$ \\
\cline { 2 - 7 } & Customer Support & $30.84 \%$ & $27.19 \%$ & $\mathbf{4 1 . 1 1 \%}$ & $32.19 \%$ & $30.13 \%$ \\
\hline \multirow{2}{*}{$\mathrm{A}$} & Social media & $\mathbf{6 6 . 2 7 \%}$ & $\mathbf{6 6 . 4 6 \%}$ & $\mathbf{6 9 . 3 5 \%}$ & $\mathbf{6 7 . 3 2 \%}$ & $\mathbf{6 6 . 8 9 \%}$ \\
\cline { 2 - 7 } & Other Ad. Channels & $23.45 \%$ & $23.87 \%$ & $21.85 \%$ & $24.32 \%$ & $21.69 \%$ \\
\cline { 2 - 7 } & $\begin{array}{l}\text { TV, Radio and } \\
\text { Newspaper }\end{array}$ & $10.28 \%$ & $9.67 \%$ & $8.80 \%$ & $8.36 \%$ & $11.42 \%$ \\
\hline
\end{tabular}

The sub-criteria with the highest criteria weights for each main criterion are shown in bold letters. All focus groups think that most important sub-criterion for Advertisement main criterion is Social Media, while it is Friend Recommendation for FFE.

Main criteria weights are multiplied with sub-criteria weights in order to sort the 23 sub-criteria with respect to all focus groups. The percentages of all 23 sub-criteria according to their degree of importance are given in Figure 5. X-axis of Figure 5 shows the names of subcriteria (abbreviations are used) and y-axis gives the weights in percentages (gray color for all students, pink color for females, blue color for males, red color for participants with an income level less than $€ 1000$ and green color for participants with an income level greater than $€ 1001$ ).

\section{Figure 5: Sub-Criteria Weights for all Focus Groups}

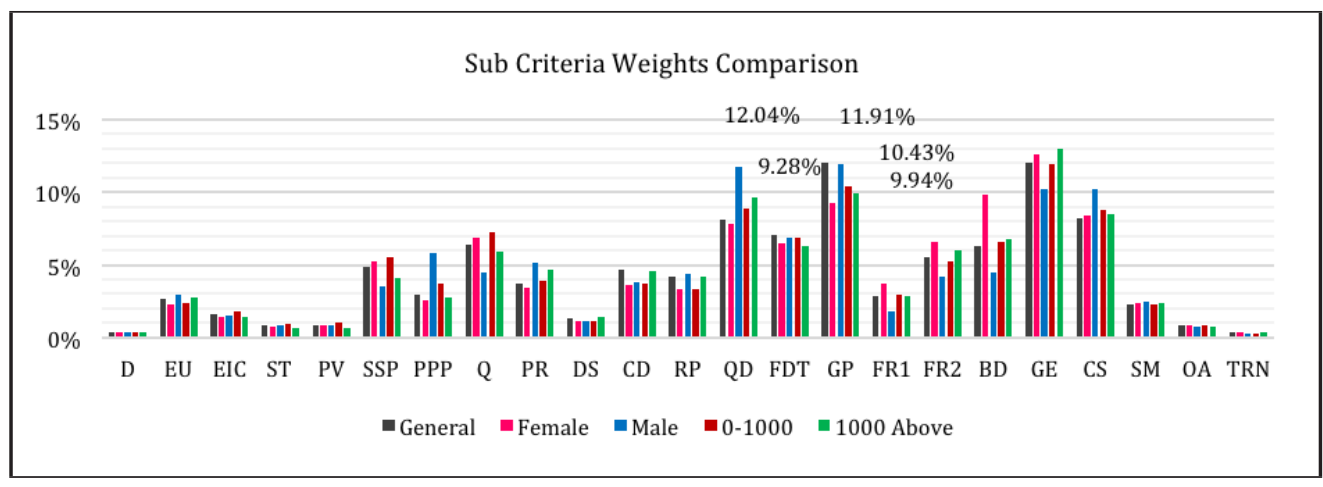

D: Design, EU: Easy to Use, EIC: Explanatory Information and Content, ST: Special Treatments, PV: Payment Variety, SSP: Security and Security Policies, PPP: Privacy and Privacy Policies, Q: Quality, PR: Price Range, DS: Different Sellers, CD: Campaigns and Discounts, RP: Return Possibilities, QD: Quality of Delivery, FDT: Fast Delivery Time, GP: Guarantee Policies, FR1: Family Recommendation, FR2: Friend Recommendation, BD: Bad Experiences, GE: Good Experiences, CS: Customer Support, SM: Social Media, OA: Other Advertisements Channels, TRN: Television, Radio and Newspaper 
The sub-criteria weights are quite important in order to understand what is more critical when students make decisions about which online shopping websites to select for shopping. The importance weights of sub-criteria change with respect to different focus groups. Such as, first five most important sub-criteria for different groups are given below:

All Participants: Guarantee Policies, Good Experiences, Customer Support, Quality of Delivery, Fast Delivery Time

Female: Good Experiences, Bad Experiences, Guarantee Policies, Customer Support, Quality of Delivery

Male: Guarantee Policies, Quality of Delivery, Customer Support, Good Experiences, Fast Delivery Time

Income less than $€$ 1000: Good Experiences, Guarantee Policies, Quality of Delivery, Customer Support, Quality

Income greater than $€$ 1001: Good Experiences, Guarantee Policies, Quality of Delivery, Customer Support, Bad Experiences

The ranking of first five sub-criteria are different for all different focus groups. So, the online shopping website owners should consider the sub-criteria weights for all participants if they do not have knowledge about gender or income levels of their customers. However, if they know the gender or income levels of their possible customers, they should improve their online shopping websites according to sub-criteria weights found with respect to gender or income level.

The weights of Guarantee Policies for different focus groups are labelled in Figure 5. It is obvious that the weights are all different for different groups. The weights found for Guarantee Policies range from $9.28 \%$ to $12.04 \%$.

The consistency test is applied for seven main criteria and their sub-criteria and the results are given in Table 13. For example, the consistency ratio for seven main criteria is 0.0298 which is less than 0.1 that means that the answers of students for main criteria comparison are consistent. As it is seen in Table 13, all calculated CR values in this study are less than 0.10 which indicate that the comparisons made by the decision maker are consistent.

\section{Table 13: Results of Consistency Ratios}

\begin{tabular}{lccc}
\hline Consistency Test & CR & Consistency Test & CR \\
\hline Main Criteria & 0.0298 & Delivery and Guarantee & 0.0398 \\
\hline Website Quality & 0.0857 & Past Experiences & 0.0386 \\
\hline Payment Methods & 0.0366 & Advertisements & 0.0980 \\
\hline Product Variety & 0.0107 & & \\
\hline
\end{tabular}

\section{Conclusion}

The share of online website in the market has increased rapidly which make it more competitive for the online shopping websites. In order to satisfy the customer demands, online shopping website owners should consider the opinions of their customers about their shopping 
websites. Thus, they can improve their website quality and service which leads to an increase on the number of customers. In this study, we determine 7 main criteria and 23 different subcriteria for those 7 main criteria. One of the most important contributions of this study is determining main and sub-criteria in such a comprehensive and detailed way by interviewing with young users of shopping websites and focusing deeply on the literature. A questionnaire is prepared and applied to 160 undergraduate university students who are from quite different age groups, income levels and gender. AHP methodology is used to find the weights of each criteria affecting university students' choice of online shopping website. This is to our best of knowledge the only study which analyze young people's opinions to find the criteria weights for online shopping website selection.

It is realized from the results that young people living in Ankara especially care for delivery and guarantee conditions this is why they do not want to waste their money. Of course, their past experience about the online shopping websites will affect their decision for the next purchase. They think that product variety comes third which affect their decision to choose which online shopping website to shop. The other 4 criteria have weights below $10 \%$. Although the shopping websites spend considerable amount of money for the advertisements, surprisingly, we see that Advertisement criteria has the least weight (3.49\%).

Regarding the sub-criteria weights; Easy to use (Accessibility and Efficiency) (48.23\%), Security and Security Policies (56.61\%), Quality (39.79\%), Guarantee Policies (38.36\%), Friend Recommendation (66.24\%). Good Experience (45.28\%) and Social Media (66.27\%) sub criteria have the highest weights for the Website Quality, Payment Method, Product Variety, Delivery and Guarantee, Family and Friend Effect, Past Experience and Advertisement main criteria respectively. The online shopping websites should consider those weights found in order to improve their quality for their customers. If they do so, they will attract more attention and increase their number of customers. If we compare 23 sub-criteria together, Guarantee policies (12.04\%), Good Experience (12.03\%) and Customer Support (8.19\%) have the highest weights respectively. We believe that our findings will give an idea for the online shopping website owners to focus which ones of those sub-criteria according to their importance.

The results are analyzed according to gender. For main criteria analysis, it is found that the most important main criteria with the highest weight is Past Experience for females. However, it is Delivery and Guarantee for male participants. We also notice that the weight of FFE is $10.31 \%$ for females while it is $6.02 \%$ for males. These significant differences are we believe because females are more emotional than males. For sub-criteria analysis, we find that among payment methods sub-criteria, Security and Security Policies is the most important one for females while it is Privacy and Privacy Policies for males. We also realize that among product variety sub-criteria, Quality is the most important one for females while it is Price Range for males.

The results are also analyzed according to income level. For main criteria, the only difference is that the fourth most important sub-criteria is Payment Method for participants with an income level less than $€ 1000$ per month while the fourth most important sub-criteria is Family and Friendship Effect for the participants with an income level above $€ 1001$ per month. We believe that this is because, the participants with low income level care about payment methods in order not to lose their money. In general, we can explain that income level 
has not a great effect on the decisions of participants with respect to main criteria. We can also explain that income level has not a great effect on the decisions of participants with respect to sub-criteria.

For all focus groups (gender, income level and all students); we find that the main criteria with highest weight percentage is Delivery and Guarantee for all students in general, males and both income levels, but it is Past Experiences for female students. Females and students with an income level greater than $€ 1001$ think that fourth most important criteria is Family Friendship Effect while it is Payment Methods for other focus groups.

One of the important contributions of this study is we analyze the criteria rankings and weights for different focus groups. Hence, we advise that the online shopping website owners should consider the sub-criteria weights for all students if they do not have knowledge about gender or income levels of their customers. However, if they know the gender of their possible customers, they should improve their online shopping websites according to criteria weights found with respect to gender.

Online shopping websites are very popular nowadays due to the Covid-19 Pandemic. People prefer to stay at home and shop online rather than going to the shopping malls or supermarkets which increase the revenues of the online shopping websites and make the online shopping market more competitive. We believe that, our study would be beneficial for the online shopping market owners since it finds and evaluates the importance weights of main and sub-criteria which have a great role on the decisions of selecting the online shopping websites to shop.

In this study, first the main and sub-criteria for the online shopping website selection are determined. Next, by using AHP methodology, the weights of main and sub criteria are found with respect to gender, income levels and for all participants. For future studies, online shopping websites can be selected as alternatives and the criteria weights found in this study can be used to evaluate those online shopping websites. AHP method or other multi criteria decision making methodologies (i.e. TOPSIS) can be used in sorting or selecting the alternative online shopping websites with respect to the main and sub criteria found in this study.

\section{References}

Aydın, Ö., Öznehir, S. \& Akçalı, E. (2009). Optimal hospital location selection by analytical hierarchical process. Suleyman Demirel University The Journal of Faculty of Economics and Administrative Sciences, 14(2), 69-86.

Celsi, M. \& Gilly, M. (2001). Shopping online for freedom, control, and fun. California Management Review, 43(2), 34-55.

Chen L, Nan, G. \& Li, M. (2018). Wholesale pricing or agency pricing on online retail platforms: The effects of customer loyalty. International Journal of Electronic Commerce, 22(4), 576-608.

Cheung, C. M. \& Lee, M. K. (2005). The asymmetric effect of website attribute performance on satisfaction: An empirical study. In Proceedings of the 38th Annual Hawaii International Conference on System Sciences (pp. 175c-175c). IEEE., 3(3), 65-86.

Çakır, E. (2016). Kısmi zamanlı olarak çalışacak öğrencilerin analitik hiyerarşi prosesi temelli VIKOR yöntemi ile belirlenmesi. Uluslararası Yönetim İktisat ve İşletme Dergisi, 12(29). 
Ducoffe, R. H. (1996). Advertising value and advertising on the web. Journal of Advertising Research, 36(5), 21-35.

Eren, T. \& Gür, S. (2017). Online alışveriş siteleri için AHP ve TOPSIS yöntemleri ile 3pl firma seçimi. Hitit Üniversitesi Sosyal Bilimler Enstitüsü Dergisi, 10(2), 819-834.

Gao, Y. (2005). Web systems design and online consumer behavior. London: Idea Group Inc. (IGI).

Hsieh, J. Y. \& Liao, P. W. (2011). Antecedents and moderators of online shopping. Social Behavior and Personality, 39(9), 1271-1280.

Hyejeong, K. \& Linda, S. N. (2009). The impact of website quality on information quality. Journal of Interactive Marketing, 23(3), 221-233.

Ilias, O., Pappas, G. \& Pateli, M. N. (2014). Moderating effects of online shopping experience on customer satisfaction and repurchase intentions. International Journal of Retail \& Distribution Management, 42(3), 187-204.

Islam, M. S. (2015). An analysis of factors affecting on online shopping behavior of consumers. European Journal of Business and Management, 7(1), 6-17.

Keeney, R. (1999). The value of internet commerce to the customer. Management Science, 45(4), 533542.

Korkmaz, O., Uysal, H. T. \& Çelik, K. (2019). İzleyicilerin pozitif ve negatif duygularının liderin hız ve etkililiği üzerindeki etkisi. Pamukkale Üniversitesi Sosyal Bilimler Enstitüsü Dergisi. 34, 203 219.

Koufaris, M. (2002). Applying the technology acceptance model and flow theory to online consumer. Information Systems Research, 13(2), 205-223.

Koyuncu, C. (2004). The impacts of quickness, price, and payment risk. Journal of Socio-Economics, 33(1), 241-251.

Lima, Y. J., Osman, A. \& Salahuddin, S. N. (2016). Factors influencing online shopping behavior: The mediating role of purchase intention. Procedia Economics and Finance, 35(1), 401-410.

Liu, X., He, M., Gao, F. \& Xie, P. (2008). An empirical study of online shopping customer satisfaction in China: A holistic perspective. International Journal of Retail \& Distribution Management, 36(11), 919-940.

López, M. F. J. \& Luna, P. (2005). Online shopping, the standard learning hierarchy, and consumers' internet expertise an American-Spanish comparison. Internet Research, 15(3), 312-334.

Mislove, A. (2007). Measurement and analysis of online social networks. IMC'07. Proceedings of the 7th ACM SIGCOMM Conference on Internet Measurement. October 24-26, San Diego, California, USA.

Naik, P. A. \& Raman, K. (2003). Understanding the impact of synergy in multimedia communications. Journal of Marketing Research, 40(4), 375-388.

Oliveira, R. C. (2007). Evidences from link between quality and loyalty in e-service. Sistemas \& Gestão, 2(1), 1-15.

Pires, G., Stanton, J. \& Eckfor, A. (2004). Influences on the perceived risk of purchasing. Journal of Consumer Behavior, 4(2), 118-131.

Saaty, T. L. (1977). A scaling method for priorities in hierarchical structures. Journal of Mathematical Psychology, 15(1), 234-281.

Sánchez-García, I., Pieters, R., Zeelenberg, M. \& Bigné, E. (2012). When satisfied consumers do not return: Variety seeking's effect on short-and long-term intentions. Psychology \& Marketing, 29(1), 15-24. 
Sheikh, J. A., Abbas, A. \& Mehmood, Z. (2015). Design consideration of online shopping website to reach to reach women in Pakistan. Procedia Manufacturing, (3), 6298-6304.

Sheikh, J. F. (2009). Cultural representation for multi-culture interaction design. internationalization, design and global development. Third International Conference IDGD, July 19-24, San Diego, CA, USA.

Smith, D. (2003). Strategic online customer decision making: Leveraging the transformational power of internet. Online Information Review, 27(6) 418-432.

Sun, C. C. \& Lin, G. T. (2009). Using fuzzy TOPSIS method for evaluating the competitive advantages. Expert Systems with Applications, 36(9), 11764-11771.

Tong, X. (2010). A cross-national investigation of an extended technology acceptance model in. International Journal of Retail \& Distribution Management, 38(10), 742-759.

Wells, J. D., Parboteeah, V . \& Valacich, J. S. (2011). Online impulse buying: Understanding the interplay between consumer impulsiveness and website quality. Journal of the Association for Information Systems, 12(1), 32-56.

Whittler, T. E. (2002). Model's race: A peripheral cue in advertising messages. Journal of Consumer Psychology, 12(4), 291-301.

Wolfinbarger, M. \& Gilly, M. C. (2001). Shopping online for freedom, control, and fun. California Management Review, 43(2), 34-55.

Woo, J., Ahn, J., Lee, J. \& Koo, Y. (2015). Media channels and consumer purchasing decisions. Industrial Management \& Data Systems, 115(8), 1510-1528.

Zhau, Z. \& Bao, Y. (2002). User's attitudes toward web advertising: Effects of Advances in Consumer Research, ACR North American Advances, 29(1), 71-78.

Zhou, L. D. (2007). Online shopping acceptance model - a critical survey of consumer factors in online shopping. Journal of Electronic Commerce Research, 8(1), 41-62. 